\title{
The Ultrastructure of a Rickettsia Pathogenic to a Saturnid Moth
}

\author{
By P. F. ENTWISTLE AND J. S. ROBERTSON \\ Insect Pathology Unit, Commonwealth Forestry Institute, \\ University of Oxford \\ AND B. E. JUNIPER \\ Botany School, University of Oxford
}

(Accepted for publication 7 June 1968)

\begin{abstract}
SUMMAR Y
The rickettsia pathogenic to the saturnid moth Samia cynthia $\times$ ricini mainly attacks mid-gut cells and multiplies in the cytoplasm. It is pleomorphic with a mean size of $\mathrm{I} \cdot 50 \mu \times 0.70 \mu$ as measured on micrographs of negatively stained preparations of purified organisms. The limiting membrane consists of two zones, the outer being about $20 \mathrm{~m} \mu$ thick and slightly rippled and the inner a finely granular layer about $30 \mathrm{~m} \mu$ thick. Actively growing organisms have a fairly dense granular cytoplasm with only few and small osmiophilic bodies; on their surfaces there are usually many small evaginations of the limiting membrane which measure up to $200 \mathrm{~m} \mu$ long, have a basal diameter of about $20 \mathrm{~m} \mu$ and often extend into the host cytoplasm. When the wall evaginations are absent the cytoplasm is less dense and osmiophilic bodies are up to $\mathrm{I} 20 \mathrm{~m} \mu$ in diameter. Some rickettsias, lying in the lumen of tracheae, have no osmiophilic bodies and very degenerate wall evaginations.
\end{abstract}

\section{INTRODUCTION}

The structure of rickettsias has received much less attention than that of bacteria. The presence of a limiting membrane was demonstrated by Plotz, Smadel, Anderson \& Chambers (1943) for Rickettsia typhi, $R$. prowazekii, $R$. rickettsii and $R$. burnetii and in $R$. mooseri and $R$. tsutsugamushi by Wissig, Caro, Jackson \& Smadel (1956).

The wall of Rickettsia prowazekii (strain Breinl) in louse gut was described by Shkolnik, Zatulovsky \& Shestopalova (1966) as consisting of two membranes. The inner one was $6 \mathrm{~m} \mu$ thick and the outer one, which appeared to be composed of three regions and was probably to be regarded as a unit membrane as conceived by Robertson (1959), was $8.5 \mathrm{~m} \mu$ thick. These authors considered that, by analogy with bacteria, the outer membrane could be designated as the cell wall and the inner one as the cytoplasmic membrane.

Stoker, Smith \& Fiset (1956) described the limiting membrane of Rickettsia burnetii as of a finely granular material 5-10 $\mathrm{m} \mu$ thick and Schaechter et al. (1957) said that of $R$. tsutsugamushi consisted of two clearly defined membranes having a total thickness of $18-30 \mathrm{~m} \mu$, while a less dense portion between these varied in thickness from 8 to $12 \mathrm{~m} \mu$. The individual membranes both ranged from 4.5 to $7.0 \mathrm{~m} \mu$. A double membrane with a total thickness of from 15 to $30 \mathrm{~m} \mu$ surrounds the protoplast of Rickettsiella melolonthae (Krieg, 1960). Roshdy (196I) described a well-defined 
limiting membrane of about 10 $\mathrm{m} \mu$ thick within which are two distinct regions in Wolbachia persicae, a rickettsia-like organism found in tissues of the tick Argas persicus. A rickettsia-like organism in the mycetome of the aphid Brevicoryne brassicae is bounded by a pair of unit membranes (Lamb \& Hinde, 1967).

In none of these, nor in the rickettsia described here, does the wall approach in complexity the structure described for bacteria such as Bacillus subtilis (Glauert, Brieger \& Allen, 1961) or Escherichia coli (Bayer \& Anderson, 1965; Pelris, 1967).

Rickettsia mooseri walls have been shown by Schaechter et al. (1957) to resemble those of bacteria (Salton, 1953) in containing both amino acids and oligosaccharides. Furthermore, muramic acid, which has been regarded as a compound specific to the mucopeptides found in bacterial cell walls, was found in walls of $R$. mooseri and $R$. typhi by Allison \& Perkins (1960), and in $R$. burnetii, $R$. tsutsugamushi, R. prowazekii and also in the organisms causing psittacosis, mouse pneumonitis, feline pneumonitis and trachoma, which belong to the psittacosis-lymphogranuloma group of intracellular pathogens by Perkins \& Allison, (1963).

Stoker et al. (1956) observed in Rickettsia burnetii a clearly defined intermediate zone of moderate density surrounding a very dense irregular central body which they postulated to be a nuclear equivalent. The intermediate zone contained granules of about $5 \mathrm{~m} \mu$ in diameter similar to those observed in the cytoplasm of bacteria. Micks, Jullian, Ferguson \& Duncan (196I) demonstrated a similarly dense central body surrounded by a granular intermediate zone in a mutualistic rickettsia-like organism in mosquito mid-gut cells. In $R$. prowazekii in louse gut and chick embryo yolk sacs there was no dense central body. The cytoplasm contained numerous small ribosomelike granules from 7 to $20 \mathrm{~m} \mu$ and 25 to $30 \mathrm{~m} \mu$ across according to the strain of $R$. prowazekii. Vacuole-like formations, $69-80 \mathrm{~m} \mu$ across, were irregularly distributed in the cytoplasm (Shkolnik, et al. 1966). In organisms from aphid mycetomes described by Lamb \& Hinde (1967), the intermediate zone was a granular network and the dense osmiophilic central body appeared to divide during binary fission of the whole organism. In Wolbachia persicae the uniformly granular cortical zone surrounded a less dense reticulated medullary area which appeared vacuolate; the two regions merged into each other with no delineating membranes (Roshdy, I96I).

Rickettsias pathogenic to insects have been observed in Coleoptera (Dutky \& Gooden, 1952; Krieg, 1955, 1965), Dictyoptera (Huger, 1964), Diptera (MüllerKögler, 1958) and Orthoptera (Vago \& Meynadier, 1965). The principle site of multiplication of these rickettsias is the fat body, but rickettsial infections of the mid gut of two saturnid moths (Lepidoptera) have been described (Entwistle \& Robertson, in press.) The observations made in this paper were on one of these (Samia (=Philosamia) cynthia $($ Drury) $\times$ ricini $(\mathrm{Bdv}$.$) ). The organism develops intracellularly$ in the cytoplasm and has not proved cultivable on bacteriological media. Preliminary serological tests show it to be related to Rickettsiella melolonthae. Like many other rickettsiae it is pleomorphic.

\section{METHODS}

The stock culture of hybrid Samia cynthia $\times$ ricini, selected for the absence of diapause, was fed on leaves of privet (Ligustrum vulgare Linn.). Larvae were infected by feeding on leaves that had been dipped in an aqueous suspension of the pathogen, prepared by triturating dead infected larvae and filtering the slurry through muslin. 
In the preparation of material for the electron microscope, the fixation schedule of Shikata \& Maramorosch (1965) was modified by the substitution of Trager solution B (Trager, 1935) for 'insect Ringer'. Tissues were embedded in Epikote resin (Shell Chemical Co., Ltd.) and sectioned on a Huxley ultramicrotome. The sections were stained with Reynolds lead citrate (Reynolds, 1963) and I \% uranyl acetate. The organisms were partially purified by passage through cellulose acetate membranes (Millipore Ltd.). Drops of the filtrate were negatively stained with I \% (w/v) tungsto-

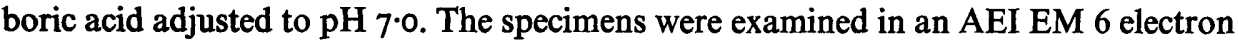
microscope at $50 \mathrm{kV}$. using double condenser illumination, at initial magnifications of I500-40,000.

\section{RESULTS}

\section{Distribution of rickettsias}

The rickettsias have a strong preference for the muscular layers which lie outside the basal membrane of the mid.gut epithelium and have been found principally in the anterior third of the mid gut. They are exclusively intracellular. In the muscular layer, they are found only in the cytoplasm of muscle cells where lacunae are formed in which the organisms lie. No such lacunae were found in healthy cells. Organisms were not seen within the nuclear membrane which remains intact even when the cytoplasm is severely affected. At times they have been seen in perinuclear lacunae.

Similar organisms are seen in the lumen of the trachea closely associated with the muscle of the anterior mid gut region. They do not seem to be in contact with the tracheal walls. In this location they very often show signs of lysis. Some organisms are found in the haemocoel, where they also show signs of degeneration, and in the lumen of the gut where they appear normal. Occasionally they are seen in the cytoplasm of fat body cells, where they do not lie in distinct lacunae.

Within the muscle cells, the majority of rickettsias close to the lacunal wall make contact with it parallel to their long axis (Pl. I, fig. I, 2).

\section{Structure of rickettsias}

External structure. The mean size of rickettsias, calculated from extracted organisms negatively-stained on Formvar membranes, is $\mathrm{I} \cdot 50 \mu$ long by $0.70 \mu$ wide. Organisms more than $\mathrm{I} \cdot 80 \mu$ long generally show clear signs of division. The rickettsiae are clearly pleomorphic, nearly coccoid forms being quite common.

A striking feature of the organisms is the presence of small evaginations of the surface, up to several hundred on a single organism. In cross-section they appeared to originate from the outer of the two bounding membranes which constitute the cell wall (Pl. 2, fig. 3 (inset)). The wall of the evaginations is consistent with the concept of a unit membrane (Robertson, 1959) showing two dark lines about $7 \mathrm{~m} \mu$ apart bounding a lighter space (Pl. 2, fig. 3, 4). The evaginations sometimes appear to be very symmetrically distributed around the rickettsias, but may also be arranged irregularly. When seen against host tissue the width of the evaginations was often irregular, but was generally about $20 \mathrm{~m} \mu$ except at the tip where it might increase to $50 \mathrm{~m} \mu$ (P1. 2, fig. 4). Their length varied between 100 and $200 \mathrm{~m} \mu$, but occasionally they were longer. When the tips were in contact with the cytoplasm of the host, the structures might bend and become distended at the tip; this distension might extend back along the evagination towards the base (P1. 2, fig. 3). 
When the rickettsias lay close to the host cytoplasm, the evaginations often penetrated the host tissue, and the rickettsias themselves were frequently partly embedded in the cytoplasm (Pl. I, fig. I, arrow).

The condition and frequency of the evaginations of the rickettsial wall varied with the location of the organism. Rickettsias with evaginations occur mainly in the lacunae in muscle cells. Here those rickettsias with the most uniformly dense cytoplasm had the greatest number of evaginations; those with large, electron transparent, light areas usually had few or no evaginations. This, too, was the condition of rickettsias seen in the lumen of the trachea and in the haemocoel. No evaginations were seen on rickettsias in the fat body or in the gut lumen.

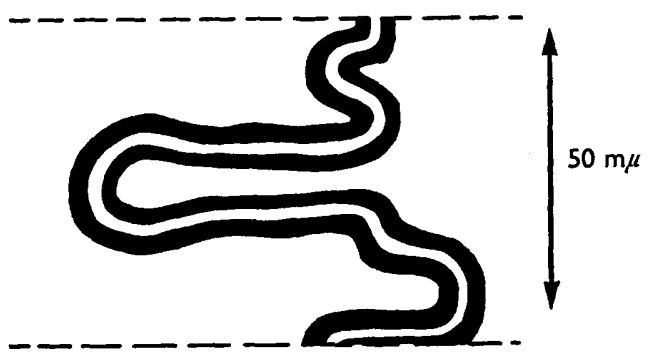

Fig. I. Profile of section through an evagination showing the continuity of the rickettsia plasmalemma with the membrane surrounding the evagination. The thickness of the section is indicated.

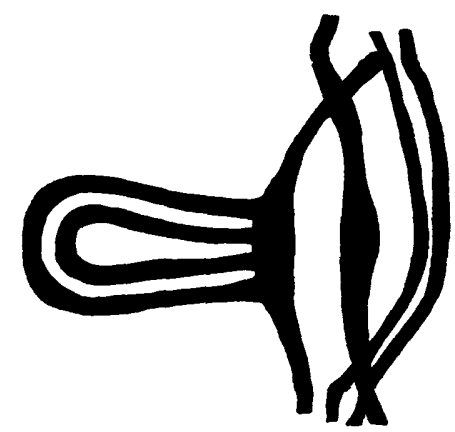

Fig. 2. Diagrammatic representation of normal view through the section in text fig. I to illustrate how the evagination may appear to be separated by a basal septum.

Structure of the wall. Interpretation of the fine structure of the wall is based on studies of fixed and stained blocks of infected host tissue and also on extracted, purified and negatively stained organisms. No studies have yet been made either using surface replicas of whole organisms or by observing the effect of enzymes and other reagents on the wall components. The organism is known, however, to have a Gramnegative reaction.

The wall consists of two distinct zones (Pl. I, fig. 2). The outer zone is $20 \mathrm{~m} \mu$ thick and appears to be made up of three or more membrane-like layers which often seem to cross one another. The intact outer surface is probably finely rippled and the dimensions of the individual ripples are considerably less than the thickness of the section which is about $50 \mathrm{~m} \mu$ (Pl. 2, fig. 4). Thus, as is indicated in Fig. I A, the intact surface 
layer may consist only of a single, but irregularly dimpled, membrane hence the appearance of a multiple membrane. The differences in density which can be seen in Fig. I B can be explained by varying degrees of reinforcement of the image through the depth of the section. This interpretation of the surface structure is supported by evidence from negatively-stained preparations (Pl. 3, fig. 5) where the surface can also be seen to be dimpled. The evaginations which arise from the surface of the rickettsia are continuous with the outer membrane and, we believe, are not separated from it by a septum at the base. The impression of a septum is probably an artifact arising from the convolute nature of the surface and the small diameter of the evaginations in relation to the depth of the section. The situation is explained diagrammatically in Fig. 2.

Within the outer membranous zone, a second zone about $30 \mathrm{~m} \mu$ thick can be seen, occasionally finely granular, but lacking distinct detail, and from which the ribosomelike granules and all other structures of the interior are completely excluded.

Internal structure. The rickettsial cytoplasm was almost uniformly granular in those organisms believed to be capable of growth. The reasons for believing that they were viable are: that they lay within lacunae, which they appeared to have formed in the muscle cells; that they showed signs of division (PI. I, fig. I) and that they had intimate contact with host cytoplasm by the bounding membrane and its evaginations. The clear areas in the cytoplasm of such organisms were small and irregular. In addition, up to three much more electron-dense granules from 40 to $60 \mathrm{~m} \mu$ in diameter distributed at random occurred in sectioned organisms (P1. 3). In some rickettsias a discrete oval or circular area of from 80 to $120 \mathrm{~m} \mu$ in diameter, granular, and having no apparent bounding membrane could be found. (Pl. 2, fig. 4). Rickettsias having one end with its evaginations in close contact with the host cytoplasm contained a similar organelle. This lay at the tip of the organism in a clear crescent shaped area of cytoplasm against the cell wall (Pl. 3, fig. 6).

In muscle cells, those rickettsias without or with few evaginations generally had much larger clear areas within their cytoplasm (arrowed in Pl. I, fig. I). Similarly, extensive clear areas were seen in the cytoplasm of organisms lying in the lumen of the trachea; these organisms had osmiophilic bodies up to three times the diameter of those in organisms in muscle cells (Pl. 3, fig. 7). Some organisms in tracheae were very distorted and their cytoplasm was retracted from the cell wall, indicating plasmolysis. They did not contain the dense osmiophilic bodies.

\section{DISCUSSION}

Our observations suggest that the internal organization of the rickettsia of Samia cynthia $\times$ ricini may vary with its location in the host animal and that this variation may reflect considerable differences in physiological activity.

Various processes of the wall of bacteria are known-flagella and fimbriae-though none have been described for rickettsias. The structure and function of flagella have been the subject of study for many years whilst fimbriae, which may have a role in the process of bacterial conjugation, have received attention more recently. Liese \& Schmid (1962) have described processes from the surface of the hyphae of wood destroying fungi.

These are of two kinds, 'micro-hyphae' which are about $0.4 \mu$ in diameter and 'mycofibrils' which are about $20 \mathrm{~m} \mu$ in diameter. Liese and Schmid suggest that both 
structures may have certain functions during the enzymic decomposition of the wood cells. Small protrusions from the cell walls of two Gram-negative bacteria, Escherichia coli (Bayer \& Anderson, 1965) and Vibrio cholerae (Chatterjee \& Das, I967) have also been described whilst Shkolnik et al. (1966) described liberation of vesicles, average diameter $50 \mathrm{~m} \mu$, from the walls of Rickettsia prowazekii strain $\mathrm{z}$ grown in chick embryo yolk sacs. In common with the evaginations of the wall of the rickettsiae described here, the protrusions in $E$. coli, $V$. cholerae and $R$. prowazekii are formed from the outer membrane only, the 'cell wall', and do not include the inner or 'cytoplasmic membrane'. However, a fuller comparison must be postponed until it is possible to establish a homologous relationship between the various cell wall components of rickettsias and bacteria.

The greatest development of micro-evaginations on this rickettsia is attained in organisms lying intracellularly, often in intimate contact with host cytoplasm, and showing a proportion of dividing individuals. This is strongly suggestive of correlation with a period of active growth or multiplication. Similarly, the development and pinching off of protrusions of the cell wall of $V$. cholerae was observed to occur only during the logarithmic phase of growth and was regarded as a possible excretory mechanism (Chatterjee \& Das, 1967). The cytoplasm of the rickettsia of S. cynthia $\times$ ricinii was much more densely filled with 'ribosomes' and less vacuolate when evaginations were present on its wall than when they were not. Similarly, there were more ribosome-like granules in $R$. prowazakii, strain $\mathrm{z}$, than in strains $\mathrm{T}$ and BREINL which did not produce vesicles in chick embryo yolk sacs. It is not known if the evaginations from the wall of this rickettsia become pinched off, but the fact that they may sometimes be intimately associated with host cytoplasm suggests a role either in enzyme secretion or in nutrient uptake, or in both. Assuming a mean diameter of $20 \mathrm{~m} \mu$ and a length of $200 \mathrm{~m} \mu$, each evagination has a surface area of $0.03 \mu^{2}$ so that if just over 300 are present on one organism its surface area would be increased by $I \cdot 0 \mu^{2}$. This would be an increase by half on the surface area of the mean organism and could possibly have an influence on its metabolic rate and capacity to degrade host tissue.

\section{REFERENCES}

Allison, A. C. \& Perkins, H. R. (I960). The presence of cell walls like those of bacteria in rickettsiae Nature, Lond. 188, 796.

BAYER, M. E. \& ANDERSON, T. F. (1965). The surface structure of Escherichia coli. Proc. natn. Acad. Sci., U.S.A. 54, 1592.

ChatterJee, S. N. \& DAS, J. (1967). Electron microscopic observations on the excretion of cell wall material by Vibrio cholerae. J. gen. Microbiol. 49, I.

DutKy, S. R. \& GOODEN, E. L. (1952). Coxiella popilliae, n.sp. a rickettsia causing blue disease of Japanese beetle. J. Bact. 63, 743 .

ENTwISTLE, P. F. \& RoBERTSON, J. S. (1968). Rickettsiae pathogenic to two saturnid moths. J. Invert. Path. (in Press).

Glauert, A. M., Bribger, E. M. \& Allen, J. M. (196I). The fine structure of vegetative cells of Bacillus subtilis. Expl. Cell. Res. 22, 73.

HugER, A. (1964). Eine Rikettsiose der Orientalischer Schabe, Blatta orientalis L., verursacht durch Rickettsiella blattae nov.spec. Naturwissenschaften 1, 22.

KRIEG, A. (1955). Licht-und elektronmikroskopische Untersuchungen zur Pathologie der 'Lorscher Erkrankung' von Engerlingen und zur Zytologie der Rickettsia melolontha nov.spec. Z. Naturf. ro6, 34.

KRIEG, A. (1960). Elektronmikroskopische Untersuchungen zur Rickettsiose von Melolontha melolontha (L.) an Hand von UltraDunnschnitten, $Z$. Naturf. 15 b, 31 . 
KRIEG, A. (1965). Uber eine neue Rickettsie aus Coleopteren, Rickettsiella tenebrionis nov.spec. Naturwissenschaften 6, 144.

LAMB, K. P. \& HINDE, R. (1967). Structure and development of the mycetome in the cabbage aphid, Brevicoryne brassicae. J. Invert. Path. 9, 3.

LIESE, W. \& SCHMID, R. (1962). Elektronmikroskopische Untersuchungen über den Abbau des Holzes durch Pilze. Angew. Bot. 36, 291.

Micks, D. W., Jullian, S. R., Ferguson, M. J. \& Duncan, D. (196I). Micro-organisms associated with mosquitoes: II. Location and morphology of micro-organisms in the mid-gut of Culex fatigans Weidemann and certain other species. J. Insect. Path. 3, 120.

MÜLLER-KöGLER, E. (1958). Eine Rickettsiose von Tipula paludosa Meig.durch Rickettsiella tipulae nov.spec. Naturwissenschaften 45, 248.

PeLris, S. DE (1967). Ultrastructure of the cell wall of Escherichia coli and the chemical nature of its constituent layers. J. Ultrastructure Res. 19, 45.

Perkins, H. R. \& Allison, A. C. (1963). Cell-wall constituents of Rickettsiae and Psittacosislymphogranuloma organisms. J. gen. Microbiol. 30, 469.

Plotz, H., Smadel, J. G., Anderson, T. F. \& Chambers, L. A. (1943). Morphological structure of rickettsiae. J. exp. Med. 77, 355 .

ReYNolds, E. S. (1963). The use of lead citrate at high $\mathrm{pH}$ as an electron opaque stain in electron microscopy. J. cell Biol. 17, 208.

ROBERTSON, J. D. (1959). The ultrastructure of cell membranes and their derivatives in the structure and function of sub-cellular components. Biochem. Soc. Symp. 16, 3.

RoshDY, M. A. (I961). Observations by electron microscopy and other methods on the intracellular Rickettsia-like Micro-organisms in Argas persicus. Oken (Ixodoidea, Argasidae). J. Insect. Path. 3, 148.

SALTON, M. R. J. (1953). Studies of the bacterial cell walls. IV. Composition of some gram-positive and gram-negative bacteria. Biochim. biophys. Acta 10, 512.

Schaechter, M., Tousimis, A. J., Cohn, Z. A., Rosen, H., Campbell, J. \& Hahn, F. E. (1957). Morphological, chemical and serological studies of the cell walls of Rickettsia mooseri. J. Bact. 74, 822.

ShiKata, E. \& Maramorosch, K. (1965). Electron microscopic evidence for the systemic invasion of an insect host by a plant pathogenic virus. Virology 27, 46I.

ShKolnik, I. Y., Zatulovsky, B. G. \& Shestopalova, N. M. (1966). Ultrastructure of Rickettsia prowazeki. An electron microscope study of ultrathin sections from infected louse guts and chick embryo yolk sacs. Acta Virologica 10, 260-265.

Stoker, M. G. P., SMITH, K. M. \& Fiset, P. (1956). Internal structure of Rickettsia burnetii as shown by electron microscopy of thin sections. J. gen. Microbiol. 15, 632 .

TRAGER, W. (1935). Cultivation of the virus of grasserie in silk worm tissue cultures. J. exp. Med. 6r, 501 .

VAGo, C. \& MeYNAdIER, G. (1965). Une rickettsiose chez le criquet pelerin (Schistocerca gregaria Forsk.) Entomophaga ro, 307.

Wissig, S. L., Caro, L. G., Jackson, E. B. \& SMadel, J. E. (1956). Electronmicroscopic observations on intracellular rickettsiae. Am. J. Path. 32, 11 I 7.

\section{EXPLANATION OF PLATES}

Plate I

Fig. I. A group of rickettsias within lacunae of the host tissue. All of the rickettsias in this micrograph are in contact with the host tissue and some are partially embedded in it. Division appears to have taken place already in one rickettsia and to be under way in another.

Fig. 2. A group of rickettsias within a lacuna of the host tissue. The broad arrow indicates a rickettsia deeply embedded in the host tissue and the narrow arrows electron translucent areas in rickettsias without evaginations.

Plate 2

Fig. 3. Part of a single rickettsia in contact with the host tissue. The evaginations from the rickettsia are penetrating into the host tissue and are frequently distended at the tip. The inset illustrates a single 
evagination at high magnification showing the continuity of the plasma membrane of the rickettsia and the 'unit membrane' structure.

Fig. 4. A single rickettsia free in a lacuna. Large numbers of evaginations project from the surface some of which appear to be septate at the base (see text). A finely granular, circular area (large arrow), a smaller electron-dense granule (small arrow) and several electron-translucent areas can be seen.

\section{Plate 3}

Fig. 5. A group of rickettsias after negative staining with phosphotungstic acid. Two of the rickettsias show signs of division.

Fig. 6. Two rickettsias with their tips embedded in the host tissue. At the embedded end lies a crescentshaped, electron-translucent area with a darker granule embedded within it.

Fig. 7. Rickettsias lying in the lumen of a trachea, showing large osmiophilic bodies, large clear areas in the cytoplasm and degenerate evaginations of the wall. 
Journal of General Microbiology, Vol. 54, No. I

Plate I
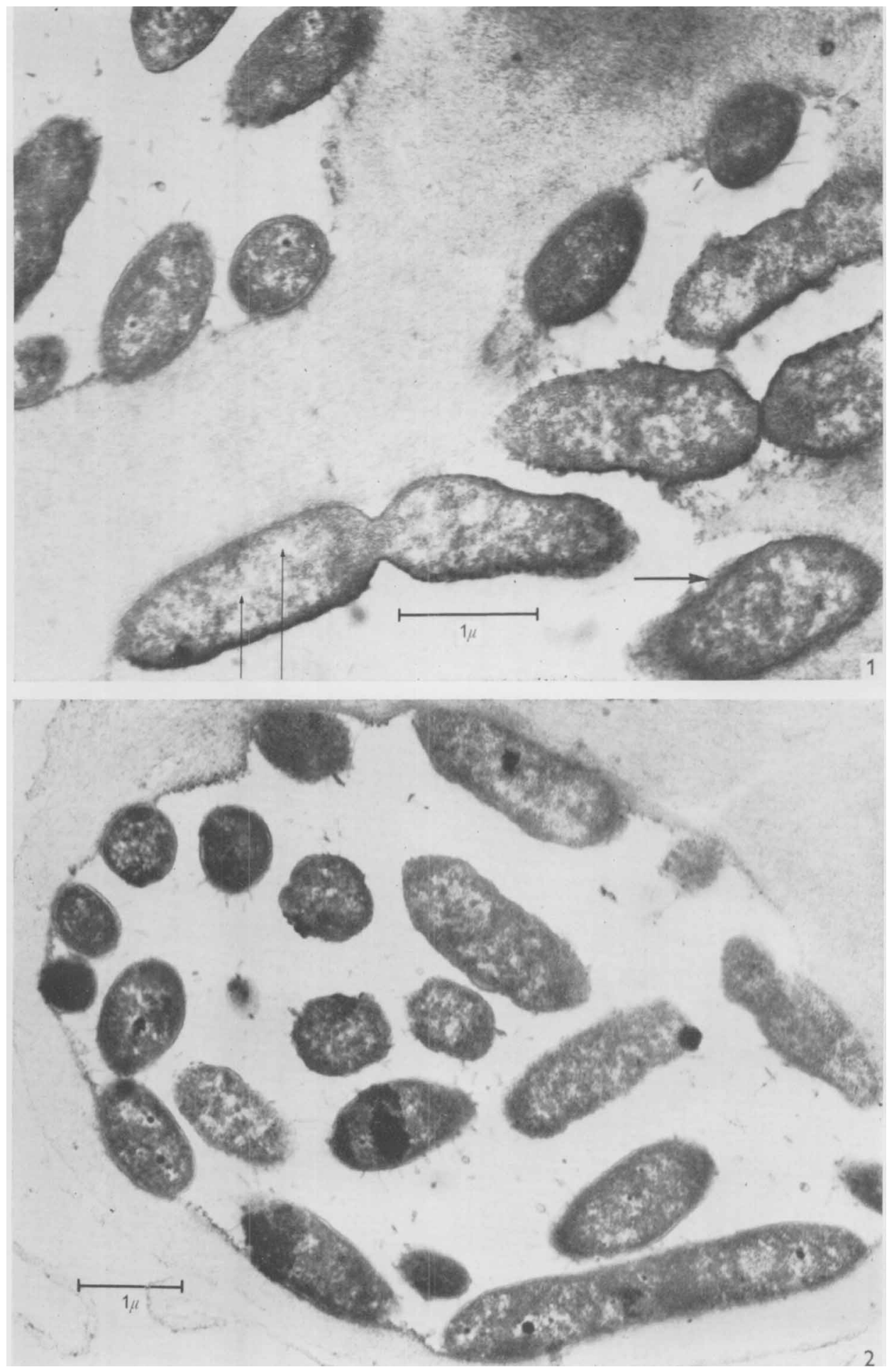

P. F. ENTWISTLE AND OTHERS

(Facing p. 104) 
Journal of General Microbiology, Vol. 54, No. I

Plate 2
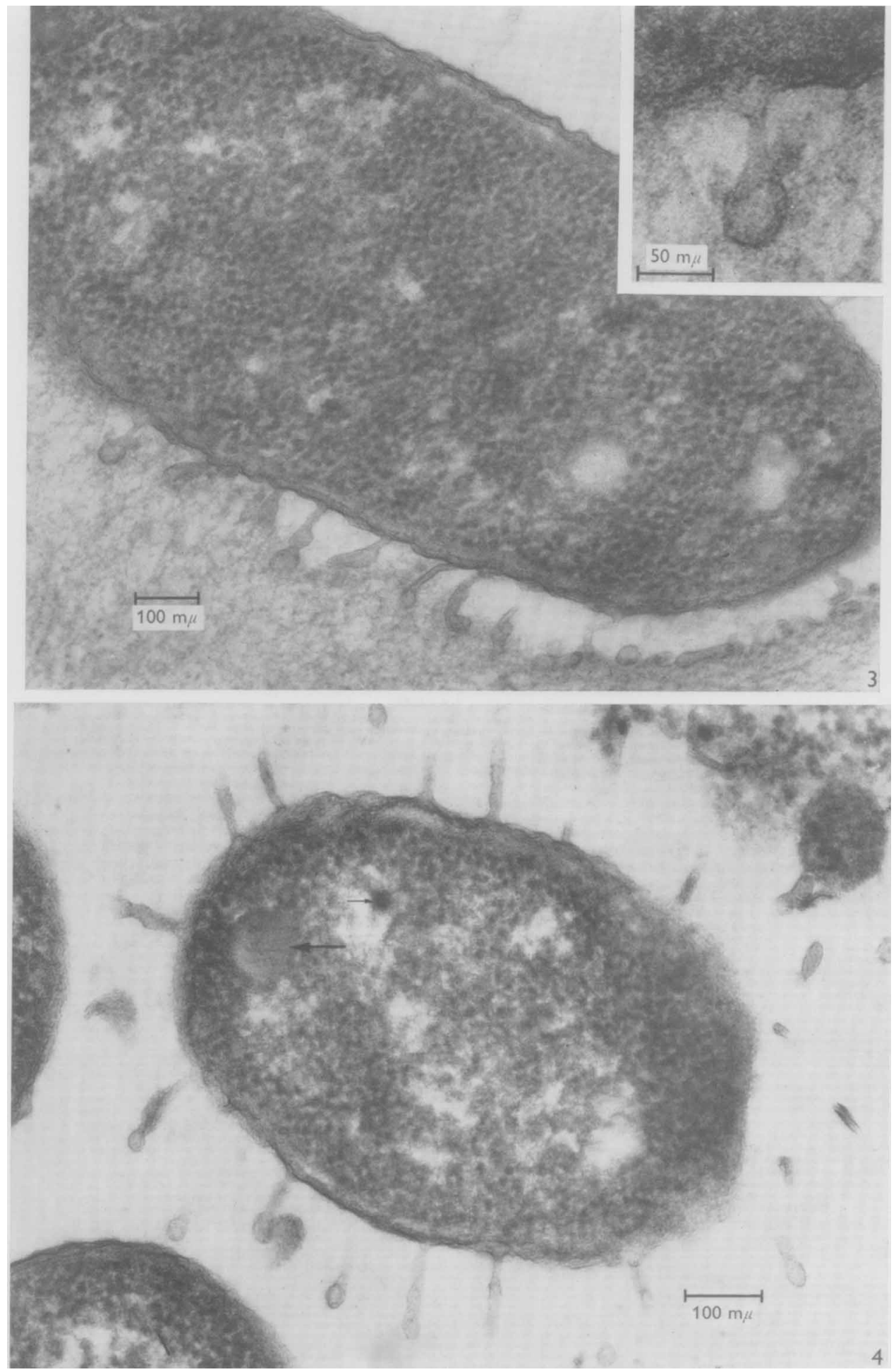

P. F. ENTWISTLE AND OTHERS 
Journal of General Microbiology, Vol. 54, No. I

Plate 3
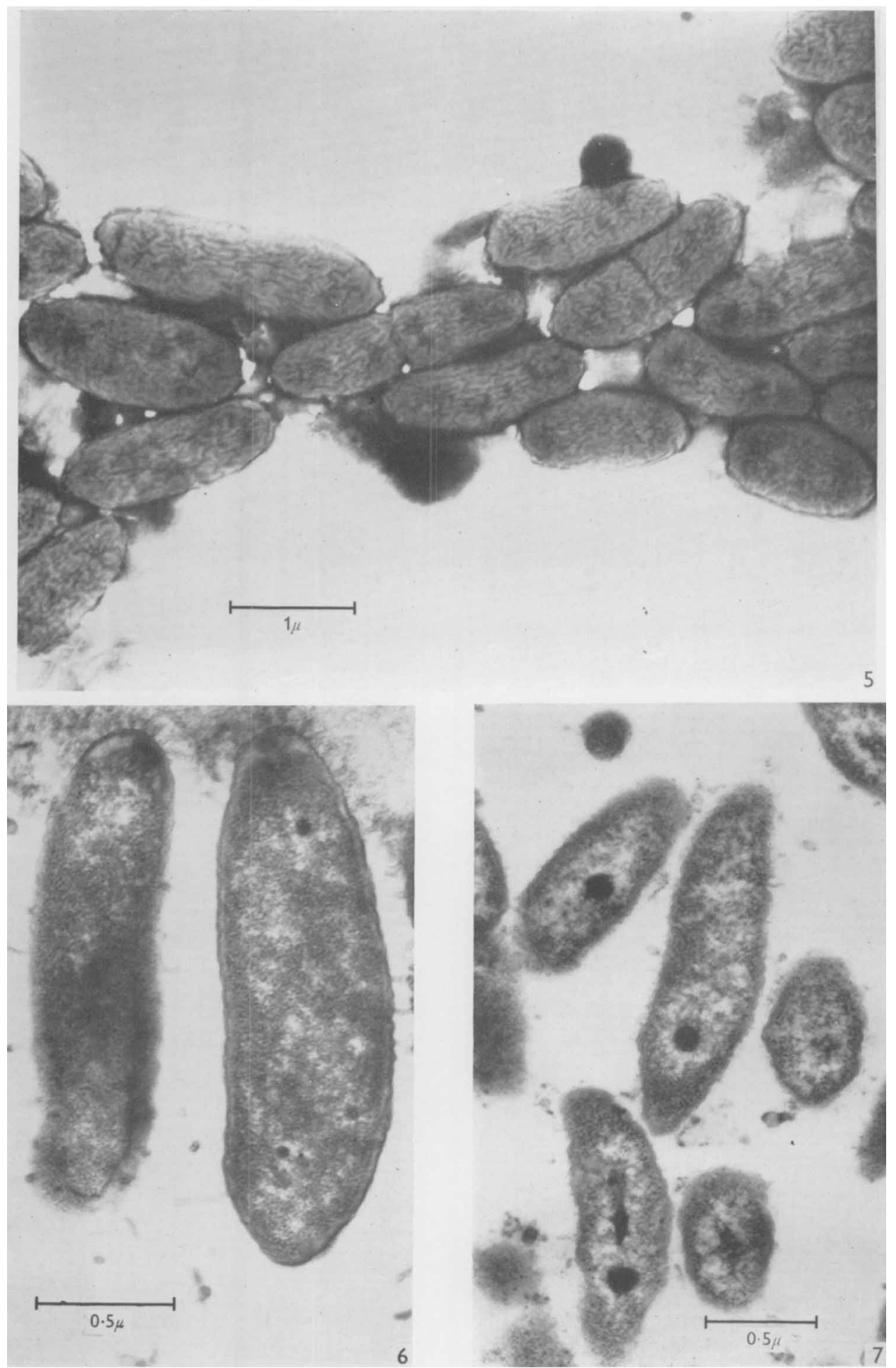

P. F. ENTWISTLE AND OTHERS 